\title{
Gastrointestinal Inherited Polyposis Syndromes
}

Mary P. Bronner, M.D.

University of Washington School of Medicine, Seattle, Washington

Mod Pathol 2003;16(4):359-365

\section{INTRODUCTION}

Many polyposis syndromes involve the gastrointestinal (GI) tract (Tables 1-2; 1-3). These include both nonhereditary (Table $1 ; 3$ ) and hereditary types (Table 2; 1, 2). Tremendous advances have accrued in recent years regarding the underlying genetics of the known hereditary GI polyposis syndromes. The causative genes are now known in all seven of the major hereditary GI polyposis syndromes (Table 2; 4-18). The genetic advances will be reviewed, along with the clinicopathologic features of these syndromes. Cancer predisposition will be emphasized.

Genetic testing is now available for all of the GI polyposis syndromes and can be readily accessed through GeneTests-GeneClinics on the Internet at www.genetests.org. The Website is a U.S. government-funded public medical genetics resource for healthcare providers and researchers and is available at no cost. The site's mission statement is as follows: "providing current, authoritative information on genetic testing and its use in diagnosis, management, and genetic counseling."

\section{Familial Adenomatous Polyposis}

\section{Clinical Aspects}

Familial adenomatous polyposis (FAP) and its variant phenotypic syndromes, attenuated FAP (AFAP), Gardner's syndrome, and Turcot's syndrome, are different manifestations of a single autosomal-dominant disorder caused by germline mutation of the adenomatous polyposis coli (APC) gene (17). The disease frequency is 1 in 8300 to 1 in 14,025 live births, and there is an equal gender and

Copyright () 2003 by The United States and Canadian Academy of Pathology, Inc.

VOL. 16, NO. 4, P. 359, 2003 Printed in the U.S.A

Date of acceptance: January 8, 2003.

Address reprint requests to: Mary P. Bronner, M.D., Department of Pathology, University of Washington, Box 356100, 1959 NE Pacific St., Seattle, WA 98195-6100; fax: (206) 598-4928; e-mail: bronner@u.washington.edu.

DOI: 10.1097/01.MP.0000062992.54036.E4 worldwide distribution. FAP patients express a variety of extraintestinal manifestations (see below), but all have adenomatous (dysplastic) polyps of the gastrointestinal tract that predispose to a high rate of adenocarcinoma (Table 3 ). The age of polyposis diagnosis is variable, but colonic adenomas generally begin to emerge in the 2nd decade, and by the 4 th decade, the majority of affected individuals have developed polyps. The average age at diagnosis for new probands is in the mid-30s $(17,19)$. Colonic adenocarcinoma is inevitable if the patient is left untreated (19). Upper gastrointestinal adenomas and adenocarcinomas may also develop in FAP, including those of the small intestine and, less commonly, the stomach (Table $4 ; 2,20)$. In particular, the periampullary region is commonly involved and, unfortunately, is the most difficult to clinically manage (Tables $4-5 ; 2,20$ ).

\section{FAP Variant Phenotypes}

The classic form of FAP has innumerable colonic adenomas that by definition number $>100$ but usually range into the thousands (Fig. 1). Variant syndromes include attenuated familial adenomatous polyposis (AFAP) and Gardner's and Turcot's syndromes (17).

\section{Attenuated FAP}

The attenuated form derives its name from the diminished number of polyps in these patients, averaging around 30 adenomas within the colon, but with prominent variation within families. Colonic cancer in AFAP patients develops an average of 12 years later than in patients with classic FAP. Upper tract lesions and extraintestinal manifestations develop in AFAP as in classic FAP $(17,21)$.

\section{Gardner's Syndrome}

The numerous extracolonic manifestations that may develop in FAP are noted in Table 5. These additional manifestations were termed Gardner's syndrome in the older literature, especially in regards to the development of desmoid tumors, which are seen in approximately $10 \%$ of FAP patients (22). These tumors may be aggressive, difficult to cure, and can result in significant morbidity 


\section{TABLE 1. Non-Hereditary GI Polyposes}

- Inflammatory and postinflammatory

- Hyperplastic

- Lymphoid

- Reactive lymphoid hyperplasia

- Lymphoma

- Lipomatosis

- Angiomatosis

- Leiomyomatosis

- Pneumatosis cystoides intestinalis

- Cronkhite-Canada syndrome

TABLE 2. Classification of Hereditary GI Polyposis Syndromes (Gene)

- Familial adenomatous polyposes

- Adenomatous polyposis coli (APC)

- Gardner, Turcot, Attenuated (APC)

- Hamartomatous polyposes

- Peutz Jeghers syndrome (STK11)

- Familial juvenile polyposis (SMAD4 or BMPR1A)

- Cowden's disease (PTEN)

- Intestinal ganglioneuromatosis (varying syndrome genes)

- Ruvalcaba-Myrhe-Smith syndrome (PTEN)

- Tuberous sclerosis (TSC1)

\section{TABLE 3. FAP Syndrome}

\begin{tabular}{ll}
\hline Inheritance: & $\begin{array}{c}\text { Autosomal dominant }(75 \% \text { familial, } \\
25 \% \text { new })\end{array}$ \\
Gene: & APC on $5 \mathrm{q} 21-22(\sim 100 \%)$ \\
Location of polyps and cancers: & $\begin{array}{c}\text { Colon and rectum } \gg \text { stomach and } \\
\text { small bowel }\end{array}$ \\
Extraintestinal manifestations: & $\begin{array}{c}\text { Desmoids }(10 \%), \text { skull and mandible } \\
\text { osteomas, CHRPE, dental } \\
\text { alterations, epidermal cysts, other } \\
\text { cancers }\end{array}$ \\
Other associations: & Fundic gland polyposis
\end{tabular}

* CHRPE $=$ congenital hypertrophy of retinal pigmented epithelium.

TABLE 4. Relative Risk of Upper GI Cancer in FAP

\begin{tabular}{lcccl}
\hline \multicolumn{1}{c}{ Site } & $\begin{array}{r}\text { Number of } \\
\text { Carcinoma }\end{array}$ & RR & $\begin{array}{c}\text { 95\% Confidence } \\
\text { Limits }\end{array}$ & $P$ \\
\hline Duodenum & 7 & 331 & $132-681$ & $<0.001$ \\
Ampulla & 4 & 124 & $34-317$ & $<0.001$ \\
Gastric & 2 & 2.4 & $0.29-9$ & NS \\
Non-duodenal & 1 & 12.7 & $0.32-71$ & NS \\
\hline
\end{tabular}

Based on follow-up of 1391 patients $(18,679$ pt-yrs).

From: Offerhaus GJA, et al. Gastroenterology 1992;102:1980.

and mortality in FAP patients. Desmoid tumors in FAP patients also develop outside the abdomen, including in such unusual places as the breast (23).

\section{Turcot's Syndrome}

Turcot's syndrome results from distinct germ-line defects in either the APC gene (FAP) or the DNA mismatch repair genes (HNPCC). FAP/Turcot patients make up approximately $75 \%$ of these patients, who develop CNS cerebellar medulloblastomas in addition to their adenomatous polyposis (24). HNPCC/ Turcot patients make up the remaining $25 \%$, and they manifest CNS glioblastoma multiforme (24).

\section{Gastric Fundic Gland Polyposis and Foveolar Dysplasia}

Fundic gland polyps commonly develop in FAP. They are similar to sporadic-type fundic gland pol-
- Adenomas/carcinomas of stomach, small intestine

- Fundic gland polyps of stomach + /- foveolar dysplasia

- Desmoid tumors (fibromatosis)

- Osteomas, fibromas, lipomas, nasopharyngeal angiofibromas

- Carcinoma of thyroid, biliary tree, liver, pancreas

- CNS meduloblastoma

- Congenital hypertrophy of retinal pigmented epithelium (CHRPE)

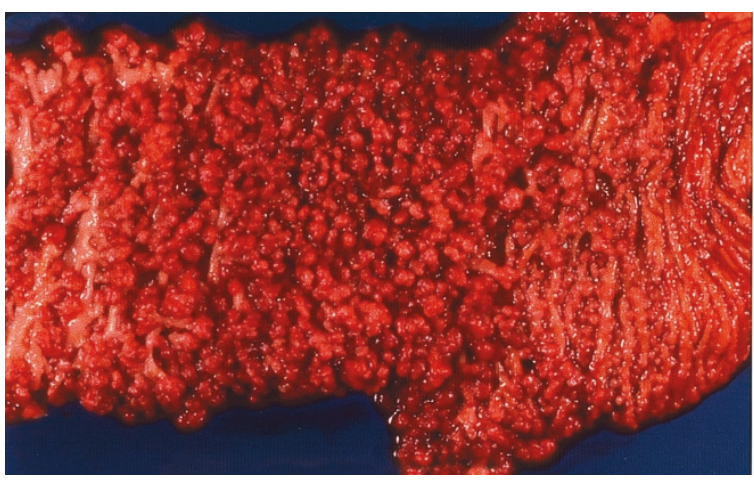

FIGURE 1. Colectomy resection specimen demonstrating classic familial adenomatous polyposis (FAP) with thousands of adenomatous polyps.

yps, with the exception that in FAP they may also have dysplasia of the surface foveolar epithelium (Fig. 2). In fact, foveolar dysplasia in a gastric fundic gland polyp appears to be an excellent marker of FAP, as it is rare in sporadic-type fundic gland polyps (25).

\section{FAP Genetics}

It is now known that the classic and variant FAP forms derive from mutation in the APC gene on chromosome 5q21-22 (Table 6; 26, 27). Approximately $75 \%$ of FAP patients inherit their genetic mutation and, therefore, have a parent and possibly
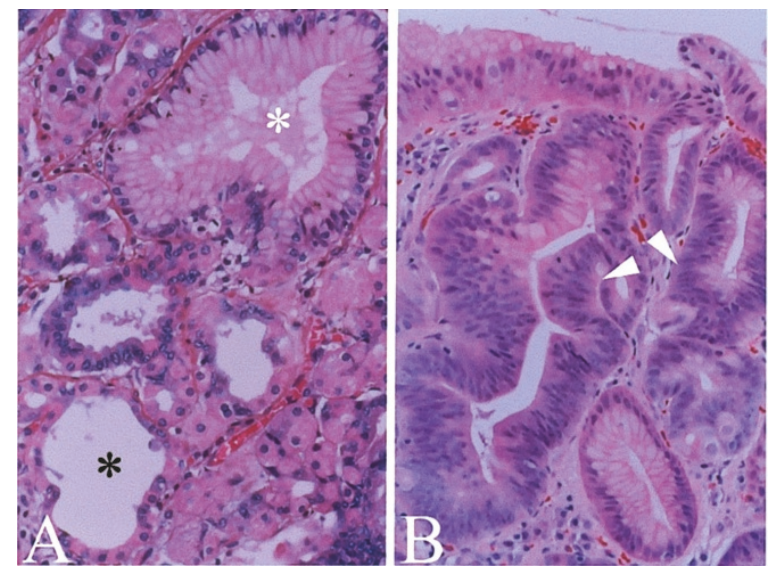

FIGURE 2. Gastric fundic gland polyp in FAP (A) showing cystically dilated fundic glands lined by parietal and chief cells (black asterisk), admixed with mucinous glands (white asterisk). Foveolar dysplasia (B) at the surface of a fundic gland polyp (arrowheads) strongly suggests FAP. 
- Large "gatekeeper" colorectal cancer gene on 5q21-22 with multiple protein functions: cell adhesion, signal transduction and transcriptional activation

- Over 300 known mutations

- Classic FAP: mutations in central exons

- Attenuated FAP: mutations at 3' \& 5' ends

- Gardner's/Turcot's Syndromes: no specific mutation location

From: Laurent-Puig P, et al. Nucleic Acids Res 1998;26:269; Giardiello FM, et al. Gastroenterology 2001;121:198.

other relatives with the mutation. The remaining $25 \%$ have a new mutation, rather than an inherited one (27). The gene itself is very large, and the reported mutations now number $>300$ (26). Mutation screening is difficult because of their distribution throughout the gene and the gene's large size (see below). The attenuated FAP variant tends to develop from mutations in the 3 ' and 5 ' regions of the gene, whereas the classic form with thousands of polyps, tends to develop from more central mutations. Other genotype-phenotype correlations have also been reported, but even patients within the same family with identical mutations may manifest pronounced phenotypic heterogeneity (17).

\section{FAP Molecular Diagnosis}

Molecular diagnosis is now available for FAP (Table 7 ; 17) and currently includes standard linkage analysis, direct sequencing, protein truncation testing (PTT), and the more recently developed refinement of conversion PTT. Fortunately, most of the known mutations in APC result in a shortened or truncated protein. The PTT test combines transcription and translation tests to take advantage of this phenomenon. The truncated protein is ultimately identified as the endpoint of the assay. The sensitivity of this test is imperfect, although it is between 80 and $90 \%$. A recent improvement in the sensitivity to $96 \%$ uses a conversion technique to test individual alleles and holds much promise for FAP genetic testing (28).

\section{FAP Screening and Treatment Guidelines}

FAP screening guidelines (Table $8 ; 17$ ) and treatment recommendations (Table 9; 17, 29, 30) have been endorsed by the American Gastroenterological Association (AGA) Clinical Practice Committee.

\section{TABLE 7. Molecular Diagnosis in FAP (Sensitivity)}

- Linkage analysis: requires two affected family members ( 99\%)

- Protein Truncation Test or PTT (80-90\%)

- Conversion PTT $(96 \%)$

- Sequencing $(>90 \%)$

From: Giardiello FM, et al. Gastroenterology 2001;121:198.
- First degree relative mutation screening at age ten ( $80-90 \%$ sensitive)

- No mutation, then periodic flexible sigmoidoscopy from age 12-50; thereafter routine colorectal cancer screening

- Upper endoscopy every 6 months to 4 years and annual thyroid examination

- Alpha-fetoprotein (AFP) serum screening in at risk children (hepatoblastoma in 1:150 in FAP patients)

From: Giardiello FM, et al. Gastroenterology 2001;121:198.

TABLE 9. FAP Treatment Guidelines

- Colectomy at diagnosis; may delay in teens with small adenomas $(<6 \mathrm{~mm})$

- COX-2 inhibitors

- Retained rectum adenoma prevention or elimination: efficacious in short term

- Ileal pouch: data not in yet

- Duodenal adenomas: no benefit in small controlled trial

From: Nugent KP, et al. Br J Surg 1993;80:1618; Steinbach G, et al. New Engl J Med 2000;342:1946.

\section{PEUTZ-JEGHERS SYNDROME}

\section{Clinical Aspects}

Peutz-Jeghers syndrome (PJS) is an autosomaldominant condition with an estimated incidence of 1 in 120,000 births $(2,18)$. Approximately $50 \%$ of cases are familial, and 50\% have new mutations. The syndrome is defined by a gastrointestinal hamartomatous polyposis, mucocutaneous melanin spots, and an elevated risk for a wide array of malignancies (Table 10). The melanin spots of PJS are present in $>95 \%$ of patients and occur most commonly on the lips (95\%) and buccal mucosa (66-83\%) but are found also on circumoral and facial skin around the eyes and nose, on the palms and soles, and on the digits $(1,2,18,31)$. The lip and circumoral spots tend to fade with age, whereas the buccal spots generally remain visible $(1,2,31-34)$.

The hamartomatous polyps of PJS are most frequent in the small bowel (64-96\% of cases) but are only slightly less frequent in the stomach and colon in many reported series $(1,2,32,33)$. Because rectal polyps have been reported in only $24-32 \%$ of cases, sigmoidoscopy is diagnostically less useful in PJS than it is in familial adenomatous polyposis (FAP; 2). The polyps of PJS are composed of normal elements indigenous to the site in which they arise, but the polyps have markedly abnormal architec-

TABLE 10. Peutz-Jeghers Syndrome (PJS)

\begin{tabular}{|c|c|}
\hline Inheritance: & $\begin{array}{l}\text { Autosomal dominant (50\% familial, } 50 \% \\
\text { sporadic) }\end{array}$ \\
\hline Gene: & STK11 on $19 p 13(70 \%)$ \\
\hline Location of polyps: & Small bowel $>$ stomach, colon \\
\hline Malignant potential: & At least $10-20 \%$; entire GI tract \\
\hline Extraintestinal manifestations: & $\begin{array}{l}\text { Melanin spots on lips, buccal mucosa, } \\
\text { digits; gonadal tumors; high } \\
\text { prevalence of pancreatic, gastric, } \\
\text { endocervical, breast (bilateral), and } \\
\text { other cancers }\end{array}$ \\
\hline
\end{tabular}


ture. Histologically, the lesions characteristically possess a frondlike growth pattern with normal epithelium. Smooth muscle forms an important component of these polyps, and it extends in an arborizing pattern from the muscularis mucosae into the polyp head (Fig. 3; 2).

\section{PJS and Benign Misplaced Epithelium}

Benign glands in PJ polyps may be surrounded by smooth muscle and extend into the submucosa, the muscularis propria, or even completely through the intestinal wall as benign misplaced epithelium (Fig. 3B; 2, 35, 36). Misplaced epithelium occurs in approximately $10 \%$ of small bowel PJ polyps and appears to be a phenomenon confined to the small bowel lesions (36). A rare example with misplaced dysplastic epithelium has been reported (35). The benign nature of misplaced epithelium is recognized by the accompanying lamina propria investing the glands, regardless of the dysplastic or normal nature of the epithelium. As a rule, dysplasia within PJ polyps is rare, and most examples of benign misplaced epithelium in these polyps contain normal, nondysplastic epithelium $(2,35,36)$.

\section{PJS: A Premalignant Condition}

Carcinoma of the gastrointestinal tract is a frequent complication of PJS (Table $11 ; 37,38$ ). Thus, PJS is now one of the several hereditary GI cancer syndromes $(18,37,38)$. Well-documented reports of GI carcinoma in PJS have appeared (esophageal, gastric, small bowel, and colonic), and in some cases, associated dysplasia has been observed within the hamartoma itself $(2,34)$. Most of the reported carcinomas of the gastrointestinal tract in PJS patients have not had evidence of origin from a hamartoma but rather derive from co-existing adenomas (2). The risk of nongastrointestinal carcinomas in PJS patients is 15 times greater than the expected rate in the general population (Table 11) and includes pancreatobiliary, lung, and breast (bilateral) adenocarcinomas (32, 37-38). In fact, a 100fold excess of pancreatic cancers has been noted in PJS patients in one large kindred (32).

TABLE 11. Cancer in PJS: Meta-Analysis of 210 Patients

\begin{tabular}{lcl}
\hline \multicolumn{1}{c}{ Site } & Relative Risk & $\begin{array}{c}95 \% \text { Confidence } \\
\text { Limits }\end{array}$ \\
\hline Esophagus & 57 & $(2.5,557)$ \\
Stomach & 213 & $(96,368)$ \\
Small bowel & 520 & $(220,1306)$ \\
Colon & 84 & $(47,137)$ \\
Pancreas & 132 & $(44,261)$ \\
Lung & 17 & $(5.4,39)$ \\
Breast & 15 & $(7.6,27)$ \\
Ovary & 27 & $(7.3,68)$ \\
Uterus & 16 & $(1.9,56)$ \\
\hline
\end{tabular}

Overall $\sim 93 \%$ cumulative cancer risk from, age 15-64; relative risk $=$ 15.2×. From: Giardiello FM, et al. Gastroenterology 2000;119:1447.
The unusual benign ovarian tumor, termed sex cord tumor with annular tubules (SCTAT) can be identified in almost all female patients with PJS (39, 40). These tumors are usually asymptomatic, small, multifocal, and bilateral. Testicular tumors of the Sertoli cell type also occur in PJS (41). Welldifferentiated adenocarcinoma of the uterine cervix (adenoma malignum; 42) has also been described with increased frequency in PJS patients.

\section{PJS Genetics (Table 12)}

In 1997, the PJS gene was mapped to chromosome 19p13.3 using an ingenious approach combining morphological and genetic techniques (7) and was confirmed by another group using linkage analysis (4). Soon thereafter, in 1998, the PJS gene itself was cloned and characterized as the novel human serine threonine kinase STK11 $(12,43)$. Mouse knockout models also substantiate that STK11 heterozygotes develop a GI hamartomatous polyposis syndrome of the stomach and small bowel (44). This combined body of work unequivocally identifies STK11 (also termed Lkb1) as the PJS gene. This has opened genetic screening to affected families. Approximately $70 \%$ of familial PJS patients have STK11 mutations, and $30-70 \%$ of new onset cases also have mutations (43). Diagnostic testing currently involves full gene sequencing of this 23-kb gene with nine exons.

\section{PJS Management Guidelines}

Several position papers have been published on the clinical management of PJS patients and their at risk family members (Table 13; 18, 34).

\section{TABLE 12. Peutz-Jeghers Syndrome Genetics}

- Mapped to 19p by CGH and LOH on micro-dissected polyps

- 19p13.3 locus refined by linkage analysis

- Gene identified as serine threonine kinase, STK11 (also known as Lbk1)

- Genetic testing available using full gene sequencing (23 kb)

CGH = comparative genomic hybridization; LOH = loss of heterozygosity.

TABLE 13. PJS Management Guidelines

\begin{tabular}{llcc}
\hline \multicolumn{1}{c}{ Site } & \multicolumn{1}{c}{ Procedure } & $\begin{array}{c}\text { Onset } \\
\text { (Age) }\end{array}$ & $\begin{array}{c}\text { Interval } \\
\text { (Yr) }\end{array}$ \\
\hline Stomach and intestines & EGD & 10 & 2 \\
& Colonoscopy, & 10 & 2 \\
& UGI with SBFT & 10 & 2 \\
Breast & Exam and & 25 & $1-3$ \\
& mammography & & \\
Testicle & Exam & 10 & 1 \\
Ovary/uterus & Pelvic exam & 20 & 1 \\
Pancreas & EUS & 30 & $1-2$ \\
\hline
\end{tabular}

From: McGarrity TJ, et al. Am J Gastroenterol 2000;95:596.

$\mathrm{EGD}=$ endoscopic gastroduodenoscopy; UGI = upper gastrointestinal (radiology); SBFT = small bowel follow through; EUS = endoscopic ultrasound. 


\section{FAMILIAL JUVENILE POLYPOSIS}

\section{Clinical Aspects}

Juvenile polyposis syndrome (JPS; Table 14) is the most common of the hamartomatous polyposes and, like the rest, is inherited as an autosomal dominant trait with variable penetrance. Approximately $20-50 \%$ of affected individuals have a familial polyposis history. Patients may present in infancy with intussusception, rectal prolapse, GI bleeding, or a protein-losing enteropathy. In adults, the most common presentation is related to chronic or acute GI blood loss. Most of the polyps in JPS are in the rectosigmoid colon, in contrast to PJS, in which the polyps are mostly located in the small bowel. The polyps show an abundance of edematous, inflamed lamina propria stroma as their most characteristic feature (Fig. 4). In fact, the stromal elements have been shown to harbor the mutations in these hamartomatous polyps (11). The surface of the polyps is often eroded (Fig. 4). The epithelial elements are frequently cystic (Fig. 4) and may or may not be dysplastic (see below). The polyps of hereditary juvenile polyposis, in addition, are often larger and multilobated in their gross appearance and are more commonly dysplastic than their sporadic counterparts.

\section{Juvenile Polyposis Genetics}

Two different genes are known to cause JPS: the SMAD-4 gene and the BMPR1A gene, both of which are involved in the TGF- $\beta$ signal transduction pathway (Table 15; 10, 18, 45). Genetic testing is clinically available for both genes.

\section{Juvenile Polyposis Neoplastic Risk}

It is now well established that JPS patients are at markedly elevated risk for GI adenocarcinoma, pri-

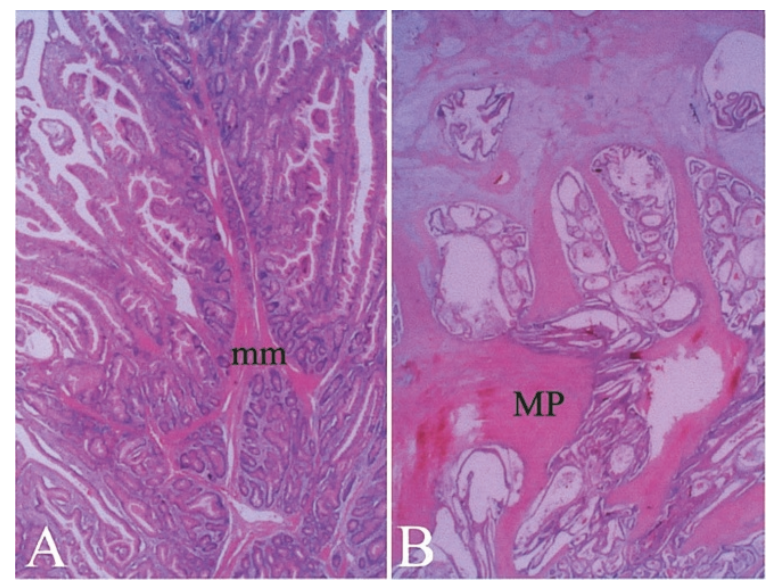

FIGURE 3. Peutz-Jeghers hamartomatous small bowel polyp (A), with its characteristic frond-like growth pattern and arborizing muscularis mucosae $(\mathrm{mm})$. Ten percent of these polyps have benign misplaced epithelium (B) that can extend deeply into the bowel wall or even through the muscularis propria (MP). This should not be mistaken for adenocarcinoma and is differentiated by virtue of the benign lamina propria that envelops the typically rounded groups of misplaced glands.
TABLE 14. Familial Juvenile Polyposis

\begin{tabular}{ll}
\hline $\begin{array}{l}\text { Inheritance: } \\
\text { Genes: }\end{array}$ & $\begin{array}{l}\text { Autosomal dominant }(20-50 \% \text { familial }) \\
\text { SMAD-4 on 18q21.1 }(50 \%) \text { or } \\
\text { BMPR1A on 10q22.3 (10-20\%) }\end{array}$ \\
Location of polyps: & $\begin{array}{c}\text { Colon and rectum } \gg \text { stomach }>\text { small bowel; } \\
\text { may be diffuse }\end{array}$ \\
Malignant potential: & $\begin{array}{c}\text { Colon cancer } 20-70 \% \text {; occurs in polyps with } \\
\text { dysplasia/adenoma } \\
\text { Extraintestinal } \\
\text { manifestations } \\
\begin{array}{c}\text { Some with hydrocephalus; hypertelorism; GU } \\
\text { forms only): }\end{array}\end{array}$ \\
\hline
\end{tabular}

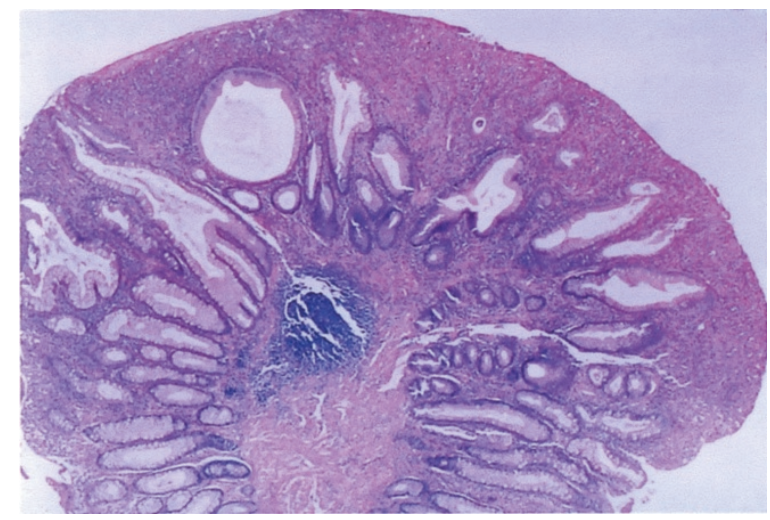

FIGURE 4. Juvenile hamartomatous polyp of the colon with its characteristic inflamed, edematous stroma; eroded surface; and cystic epithelial elements. This example is negative for dysplasia, but all juvenile polyps and particularly large and multilobulated ones should be scrutinized for neoplastic change. Epithelial surface maturation, as seen in this example, differentiates reactive/reparative change from dysplastic change.

\section{TABLE 15. Juvenile Polyposis Genetics}

- SMAD-4 gene on $18 q 21.1$

- $50 \%$ of JPS pts

- Encodes mediator in TGF- $\beta$ pathway

- Initial reports of PTEN gene INCORRECT (Cowden's)

- Stromal cells are mutated

- BMPR1A on 10q22.3

- $10-20 \%$ of JPS pts

- Upstream of SMAD-4 in TGF- $\beta$ pathway

From: Zhou XP et al. Am J Hum Genet 2001;69:704. Howe JR, et al. Nat Genet 2001;28:184. Howe JR, et al. Science 1998;280:1086.

marily colorectal cancer. The risk ranges from $20-$ $70 \%$ and increases with age (Table $16 ; 46-48$ ). All juvenile polyps should be carefully scrutinized for dysplasia, as cancer in JPS derives from neoplastic change within the juvenile polyps themselves. It is important, however, to avoid overdiagnosing reac-

\section{TABLE 16. Neoplastic Risk in Juvenile Polyposis}

- St. Mark's Hospital Registry, London 1988

- 80 patients with $22 \%$ having colon cancer; registry revisited in 1995 and projected colorectal cancer rate increased to $68 \%$ by age 60

- Coburn meta-analysis

- 218 patients with $17 \%$ GI cancer (all colonic except 1 gastric, 1 duodenal)

From: Jass JR, et al. Histopathology 1988;13:619. Coburn MC, et al. Ann Surg Oncol 1995;2:386. Desai DC, et al. Br J Surg 1995;82:14. 
tive inflammatory atypia as true dysplasia. As in all GI inflammatory disorders, the most important differential criterion is whether the epithelium matures onto the surface of the polyp, which indicates a reactive, nondysplastic condition.

\section{Juvenile Polyposis Management Guidelines}

Because of the very high risk of colonic cancer, along with the characteristic acute and chronic blood loss, close colonoscopic surveillance is recommended. Some authorities recommend colectomy by the age of 20 years for all JPS patients (Table 17; 18).

\section{PTEN HAMARTOMA TUMOR SYNDROME}

At least two GI polyposis syndromes have now been linked to mutation in the PTEN gene on chromosome 10q23.3. These include Cowden's syndrome and Ruvalcaba-Myhre-Smith syndrome, also known in the literature as Bannayan-RileyRuvalcaba syndrome. The features of both are summarized in Tables 18 and 19 (18). Histologically, the polyps are inflammatory-type polyps that are indistinguishable from juvenile polyps.

\section{TABLE 17. JPS Management Guidelines}

- Colonoscopic polypectomies every 1-3 yr

- Colectomy for

- High numbers of polyps

- Dysplastic polyps

- Uncontrolled bleeding

- Most patients, by age 20

- Total proctocolectomy with J-pouch favored due to rectal recurrences

- Upper endoscopy

- Genetic screening

From: Wirtzfeld D et al. Ann Surg Oncol 2001;8:319.

\section{TABLE 18. Cowden's Disease}

\begin{tabular}{|c|c|}
\hline Inheritance: & Autosomal dominant \\
\hline Gene: & PTEN on $10 \mathrm{q} 23.3(80 \%)$ \\
\hline Location of polyps: & Throughout GI tract (35\%) \\
\hline Malignant potential: & $\begin{array}{l}\text { None for GI lesions; increased breast ca }(25-50 \%) \\
\text { and thyroid ca ( } 10 \% \text { usually follicular); } \\
\text { ? endometrial }(5-10 \%)\end{array}$ \\
\hline $\begin{array}{l}\text { Extraintestinal } \\
\text { manifestations: }\end{array}$ & $\begin{array}{l}\text { Facial trichilemmomas; acral keratoses; oral } \\
\text { fibromas; lipomas and hemangiomas; } \\
\text { macrocephaly; Lhermitte-Duclos disease } \\
\text { (cerebellar dysplastic gangliocytoma) }\end{array}$ \\
\hline Genetic testing: & Clinically available: Full sequencing \\
\hline
\end{tabular}

TABLE 19. Ruvalcaba-Myhre-Smith Syndrome

\begin{tabular}{ll}
\hline Inheritance: & Autosomal dominant \\
Gene: & PTEN on 10q23.3 (60\%) \\
$\begin{array}{c}\text { Location of } \\
\text { polyps: }\end{array}$ & Colon; tongue \\
$\begin{array}{c}\text { Extraintestinal } \\
\text { manifestations: }\end{array}$ & $\begin{array}{c}\text { Macrocephaly, lipomas and pigmented penile } \\
\text { macules } \\
\text { Malignant }\end{array}$ \\
$\begin{array}{c}\text { potential: } \\
\text { Genetic } \\
\text { testing: }\end{array}$ & Clinically available: Full sequencing \\
\hline
\end{tabular}

- Parent Syndromes

- Multiple endocrine neoplasia, type IIB (RET)

- Von Recklinghausen disease (NF1)

- Familial ganglioneuromatosis (?RET)

- Cowden's disease (PTEN)

- Lesions located throughout the GI tract

- Very low malignant potential

- Extraintestinal manifestations vary with the parent syndrome

TABLE 21. Tuberous Sclerosis

\begin{tabular}{ll}
\hline Inheritance: & Autosomal dominant \\
Gene: & TSC1 (9q34) or TSC2 (16p13) \\
Location of polyps: & Distal colon and rectum \\
Malignant potential: & None known \\
Extraintestinal & Mental retardation; epilepsy; cutaneous \\
$\quad$ manifestations: & hamartomas (adenoma sebaceum) \\
\hline
\end{tabular}

\section{INTESTINAL GANGLIONEUROMATOSIS}

This disorder is heterogeneous in its genetic etiology and depends on the parent syndrome, as summarized in Table 20 (49). The polyps consist of neuromatous spindle cell proliferations with ganglion cells often involving the mucosa, where they do not normally reside in appreciable numbers. Genetic testing is available for the parent syndromes of MEN Type IIB, Von Recklinghausen disease, and Cowden's disease caused by RET, NF-1, and PTEN mutations, respectively.

\section{TUBEROUS SCLEROSIS}

Tuberous sclerosis patients may have benign hamartomatous polyps of the distal colon and rectum, but this is only a minor feature of the disorder. Morphologically, the polyps are inflammatory-type polyps identical in appearance to juvenile polyps. The characteristics of the syndrome are listed in Table $21(16,50)$. Genetic testing is currently available only on a research basis.

\section{REFERENCES}

1. Rustgi AK. Hereditary gastrointestinal polyposis and nonpolyposis syndromes. N Engl J Med 1994;331:1694-702.

2. Haggitt RC, et al. Hereditary gastrointestinal polyposis syndromes. Am J Surg Pathol 1986;10:871-87.

3. Ward EM, Wolfsen HC. Review article: the non-inherited gastrointestinal polyposis syndromes. Aliment Pharmacol Ther 2002;16:333-42.

4. Amos CI, Bali D, Thiel TJ, et al. Fine mapping of a genetic locus for Peutz-Jeghers syndrome on chromosome 19p. Cancer Res 1997;57:3653-6.

5. Chi SG, Kim HJ, Park BJ, et al. Mutational abrogation of the PTEN/MMAC1 gene in gastrointestinal polyps in patients with Cowden disease. Gastroenterology 1998;115:1084-9.

6. Eng C, Peacocke M. PTEN and inherited hamartoma-cancer syndromes. Nat Genet 1998;19:223.

7. Hemminki A, Tomlinson K, Markie D, et al. Localization of a susceptibility locus for Peutz-Jeghers syndrome to 19p using comparative genomic hybridization and targeted linkage analysis. Nat Genet 1997;15:87-90. 
8. Hopkin K. A surprising function for the PTEN tumor suppressor. Science 1998;282:1027-30.

9. Howe JR, Ringold JC, Hughes JH, et al. Direct genetic testing for Smad4 mutations in patients at risk for juvenile polyposis. Surgery 1999;126:162-70.

10. Howe JR, Roth S, Ringold JC, et al. Mutations in the SMAD4/ DPC4 gene in juvenile polyposis. Science 1998;280:1086-8.

11. Jacoby RF, Schlack S, Cole CE, et al. A juvenile polyposis tumor suppressor locus at 10q22 is deleted from nonepithelial cells in the lamina propria. Gastroenterology 1997;112: 1398-403.

12. Jenne DE, Reimann H, Nezu J-I, et al. Peutz-Jeghers syndrome is caused by mutation in a novel serine threonine kinase. Nat Genet 1998;18:38-43.

13. Liaw D, Marsh DJ, Li J, et al. Germline mutations of the PTEN gene in Cowden disease, an inherited breast and thyroid cancer syndrome. Nat Genet 1997;16:64-7.

14. Nelen MR, Padberg GW, Peeters EA, et al. Localization of the gene for Cowden disease to chromosome 10q22-23. Nat Genet 1996;13:114-6.

15. Roth S, Sistonen P, Salovaara R, et al. SMAD genes in juvenile polyposis. Genes Chromosomes Cancer 1999;26:54-61.

16. van Slegtenhorst $\mathrm{M}$, de Hoogt R, Hermans $\mathrm{C}$, et al. Identification of the tuberous sclerosis gene TSC1 on chromosome 9q34. Science 1997;277:805-8.

17. Giardiello FM, Brensinger JD, Peterson GM. AGA technical review on hereditary colorectal cancer and genetic testing. Gastroenterology 2001;121:198-213.

18. Wirtzfeld DA, Petrelli NJ, Rodriguez-Bigas MA. Hamartomatous polyposis syndromes: molecular genetics, neoplastic risk, and surveillance recommendations. Ann Surg Oncol 2001;8:319-27.

19. Bussey HJR. Familial polyposis coli. Family studies, histopathology, differential diagnosis, and results of treatment. Baltimore, MD: Johns Hopkins University Press; 1975.

20. Offerhaus GJ, Giardiello FM, Krush AJ, et al. The risk of upper gastrointestinal cancer in familial adenomatous polyposis. Gastroenterology 1992;102:1980-2.

21. Lynch HT, Smyrk T, McGinn T, et al. Attenuated familial adenomatous polyposis (AFAP): a phenotypically and genotypically distinctive variant of FAP. Cancer 1995;76:2427-33.

22. Gurbuz AK, Giardiello FM, Petersen GM, et al. Desmoid tumours in familial adenomatous polyposis. Gut 1994;35: 377-81.

23. Haggitt RC, Booth JL. Bilateral fibromatosis of the breast in Gardner's syndrome. Cancer 1970;25:161-6.

24. Hamilton SR, Liu B, Parsons RE, et al. The molecular basis of Turcot's syndrome. N Engl J Med 1995;332:839-47.

25. Abraham SC, Nobukawa B, Giardiello FM, et al. Fundic gland polyps in familial adenomatous polyposis: neoplasms with frequent somatic adenomatous polyposis coli gene alterations. Am J Pathol 2000;157:747-54.

26. Laurent-Puig P, Beroud C, Soussi T. APC gene: database of germline and somatic mutations in human tumors and cell lines. Nucleic Acids Res 1998;26:269-70.

27. Bisgaard ML, Fenger K, Bulow S, et al. Familial adenomatous polyposis (FAP): frequency, penetrance, and mutation rate. Hum Mutat 1994;3:121-5.

28. Laken SJ, Papadopoulos N, Peterson G, et al. Analysis of masked mutations in familial adenomatous polyposis. Proc Natl Acad Sci U S A 1999;96:2322-6.

29. Nugent KP, Farmer KCR, Spigelman AD, et al. Randomized controlled trial of the effect of sulindac on duodenal and rectal polyps and cell proliferation in familial adenomatous polyposis. Br J Surg 1993;80:1618-9.

30. Steinbach G, Lynch PM, Phillips RK, et al. The effect of celecoxib, a cyclooxygenase-2 inhibitor in familial adenomatous polyposis. N Engl J Med 2000;342:1946-52.

31. Cahn LR. Some notes on Sir Jonathan Hutchinson (18281913). Am J Surg Pathol 1979;3:563-6.

32. Foley TR, McGarrity TJ, Abt AB. Peutz-Jeghers syndrome. A clinicopathologic survey of the "Harrisburg Family" with a 49-year follow-up. Gastroenterology 1988;95:1535-40.

33. Jeghers H, McKusick VA, Katz KH. Generalized intestinal polyposis and melanin spots of the oral mucosa, lips, and digits. A syndrome of diagnostic significance. N Engl J Med 1949;241:993-1005.

34. McGarrity TJ, Kulin HE, Zaino RJ. Peutz-Jeghers syndrome. Am J Gastroenterol 2000;95:596-604.

35. Petersen VC, Sheehan AL, Bryan RL, et al. Misplacement of dysplastic epithelium in Peutz-Jeghers polyps: the ultimate diagnostic pitfall? Am J Surg Pathol 2000;24:34-9.

36. Shepherd NA, Bussey HJR, Jass JR. Epithelial misplacement in Peutz-Jeghers polyps. Am J Surg Pathol 1987;11:743-9.

37. Giardiello FM, Brensinger JD, Tersmette AC, et al. Very high risk of cancer in familial Peutz-Jeghers syndrome. Gastroenterology 2000;119:1447-53.

38. Boardman LA, Thibodeau SN, Schaid DJ, et al. Increased risk for cancer in patients with the Peutz-Jeghers syndrome. Ann Intern Med 1998;128:896-989.

39. Scully RE. Sex cord tumor with annular tubules-a distinctive ovarian tumor of the Peutz-Jeghers syndrome. Cancer 1970;25:1107-21.

40. Young RH, Welch WR, Dickersin GR, et al. Ovarian sex cord tumor with annular tubules. Cancer 1982;50:1384-1402.

41. Wilson DM, Pitts WC, Hintz RL, et al. Testicular tumors with Peutz-Jeghers syndrome. Cancer 1986;57:2238-40.

42. Gilks CB, Young RH, Aguirre P, et al. Adenoma malignum (minimal deviation adenocarcinoma) of the uterine cervix. A clinicopathological and immuno-histochemical analysis of 26 cases. Am J Surg Pathol 1989;13:717-29.

43. Trojan J, Brieger A, Raedle J, et al. Peutz-Jeghers syndrome. Molecular analysis of a three-generation kindred with a novel defect in the serine threonine kinase gene STK11. Am J Gastroenterol 1999;94:257-61.

44. Miyoshi H, Nakau M, Ishikawa TO, et al. Gastrointestinal hamartomatous polyposis in Lkb1 heterozygous knockout mice. Cancer Res 2002;62:2261-6.

45. Zhou XP, Woodford-Richens K, Lehtonen R, et al. Germline mutations in BMPR1A/ALK3 cause a subset of cases of juvenile polyposis syndrome and of Cowden and BannayanRiley-Ruvalcaba syndromes. Am J Hum Genet 2001;69:70411.

46. Desai DC, Neale KF, Talbot IC, et al. Juvenile polyposis. Br J Surg 1995;82:14-7.

47. Jass JR, Williams CB, Bussay HJR, et al. Juvenile polyposis-a precancerous condition. Histopathology 1988;13:619-30.

48. Coburn MC, Pricolo VE, DeLuca FG, et al. Malignant potential in intestinal juvenile polyposis syndromes. Ann Surg Oncol 1995;2:386-91.

49. Shekitka KM, Sobin LH. Ganglioneuromas of the gastrointestinal tract. Relation to Von Recklinghausen disease and other multiple tumor syndromes. Am J Surg Pathol 1994;18: 250-7.

50. Devroede G, Lemieux B, Masse S, et al. Colonic hamartomas in tuberous sclerosis. Gastroenterology 1988;94:182-8. 